\title{
International Experience in Treatment of Transboundary Pollution Cooperation in China And Kazakhstan
}

\author{
Almerekova Aigul * \\ Institute of Environment for Sustainable Development, \\ UNEP \\ Tongji University \\ Shanghai, China \\ aigulkz@mail.ru
}

\begin{abstract}
Air pollution, transboundary acid rain, destruction of ecosystems, sand and dust storms and water pollution and other environmental problems continue to plague China and Kazakhstan cross-border areas. Pollution problems between the two countries China and Kazakhstan has become a serious threat to regional economic and trade exchanges between the two countries, but also affected the international connections of the Eurasian plate. In this study, by analyzing the international classic example, for crossborder regional governance and the prevention of pollution, to find the similarities and differences in Kazakhstan transboundary pollution, to provide some thinking and our approach to transboundary pollution control and Kazakhstan.
\end{abstract}

Keywords- transboundary; China; Kazakhstan; Pollution; Cooperation

\section{INTRODUCTION}

As the 21th Century started, with the continuous progress of the world's industrial civilization, environmental destruction and pollution of pollutants are showing a variety and serious trend. Because of the environment is public product attributes, and the lack of a centralized "super state" institution, it is unable to turn cross border pollution into the problem of the internal.

As the world economic growth is most rapid, the most dynamic, regional connection of the Eurasian plate, East and Central Asia region in building a modern industrial system, at the same time, also suffered from the pain of the destruction of the ecological environment and the transboundary pollution. Acid rain, dust, haze, water pollution and even nuclear waste and other cross-border pollution problems in the erosion of the regional welfare, but also affect the normal economic and trade cooperation and international relations in the region. The China and Kazakhstan in the cross regional as a representative sample, in today's world wide area of concern for the transboundary environmental pollution problems of experience summary, should be able to solve problems similar to those of China and Kazakhstan to provide theory and practical basis.

There are many countries and regions in the world have suffered from cross-border pollution, such as Europe, North America has been the world's top two acid rain disaster. Accordingly, the countries of these regions also have a series of efforts to eliminate the threat of

\author{
Wenying Xu \\ Institute of Environment for Sustainable Development, \\ UNEP \\ Tongji University \\ Shanghai, China \\ aigulkz@mail.ru
}

transboundary pollution, therefor a lot of experience or lessons has been created. In this chapter, the author will review and reviewed in Europe, North America, ASEAN and other regional governance of transboundary pollution and carry out environmental cooperation process, refining specific approach and mechanism and provide empirical support for the realization of Kazakhstan bilateral regional transboundary pollution control and environmental cooperation.

\section{STATUS QUO}

Atmospheric pollution, acid rain, ecosystem damage, dust weather and water pollution and other environmental problems continue to plague the two countries in the crossborder area. Due to the regional environment and the collapse of any one ecological links are likely to break the balance of the original system of regional ecological environment. Therefore, the environmental pressures caused by the above pollution are across borders, in the region of the Sino Kazakhstan shared. It also shows that regardless of the severity of pollution, or from the complexity of governance, the governance of transboundary pollution are required in the bilateral crossborder strengthen mutual cooperation, jointly cope with transboundary pollution threat.

There is a broad geographical boundary between China and Kazakhstan, most of which are grassland animal husbandry areas, a small part of forest and desert. The environmental problems facing the two countries include grassland desertification, vegetation degradation and desertification, dust weather, pest and biodiversity protection, etc.. Environmental cooperation between China and Kazakhstan began in 1995 the government of the people's Republic of China and the government of Kazakhstan on the protection of the natural environment cooperation agreement; agreement of cooperation include: sand and soil weathering prevention and Gobi desert vegetation restoration and plant diseases and insect pests prevention, grassland pasture of rational use and protection, atmosphere and soil environmental monitoring, to prevent surface water resource depletion, the establishment of natural protection area of sanctuary, natural environmental assessment, environmental protection, basic research and human culture, and the United Nations Environment Framework Convention on coordinated action. The main ways of environmental cooperation include the 
establishment of laboratory and joint research center, the publication of the relevant environmental protection literature and other research results, the convening of the two environmental conference, etc..

\section{INTERNATIONAL EXPERIENCE}

\section{A. Finland and the former Soviet Union's cross-border acid rain cooperation}

Research chooses the case that Finland and the Soviet Union of cross-border cooperation in acid rain, not only because it is in Europe for the first time in the cross-border pollution and carry out environmental cooperation and the huge gap between the scale of both countries, as well as differences in ideology for this collaboration is added to the many political factors. These factors make it a classic case of regional cross-border pollution cooperation.

With the development of the Soviet Union's heavy chemical industry, the amount of pollution emissions increased year by year, which is the first to bear the brunt of sulfur dioxide, which is closely related to coal as the main energy. Because Finland and the former Soviet Union has a long border, these mixed in the atmosphere of sulfur dioxide caused a lot of sulfur deposition in Finland area. According to statistics, Finland and the former Soviet Union at the junction of the settlement was reached 650000 tons per year, this figure is 160000 tons of sulfur dioxide in Finland in the year more than four times. But in fact, these cross-border acid rain precursors is only the total amount of sulfur dioxide emissions of the former Soviet Union 3-4\%. Nevertheless, the sulfur deposition still to Finland brought serious losses, especially in the Kola Peninsula area. Due to the high lying in the region and is close to former Soviet industrial more developed Leningrad, suffered the most serious, brings together about $80 \%$ of the cross-border sulfur deposition. Acid rain resulted in the Kola Peninsula of the two main species Norway spruce Piecaabies and Nordic pine Pinussilvestris within a radius of $100 \mathrm{~km}$ range completely extinct; and it is estimated at least 150 years the species complete recovery. Because economy depends on forest resources great in Finland, acid rain in a certain extent damage the Finnish economy; at the same time, Finland the soil acidity due to the increase in sulfur deposition and rapidly increasing, not only exceeded the standard risk but also continuous diffusion to the whole country.

1980's years later, Finland kept on solving the problem of acid rain to do the work. On the one hand to reduce the maximum extent of their own sulfur dioxide emissions. According to statistics, in 1980 - 1987, Finland's sulfur dioxide emissions decreased by $40 \%$. On the other hand, Finland is also actively seeking environmental cooperation with the former Soviet union. Since the marginal cost of sulfur dioxide emission reduction in the former Soviet Union only equivalent to about $20 \%$ of Finland. Therefore, the former Soviet Union can in Finland pollution reduction "unilateral payment" to accept, transboundary pollution abatement, enhance the overall regional environmental quality. Bilateral in 1987 formally signed the bilateral agreement, agreed in the future will be throughout the territory of Finland and Soviet and Finnish border parts of sulfur dioxide settlement reduced by $50 \%$; and, the two countries also followed common join the European Long- range Transboundary Air Pollution Convention, CLRTAP. The problem of acid rain in the region has been solved a lot, and the sulfur deposition has been greatly reduced. But also the change of energy consumption structure in the former Soviet Union and Europe near the power plant eastward, and nuclear energy use and other factors.

\section{B. The United States and Canada, cross-border acid rain cooperation}

North America is one of the most serious areas of the world's three largest cross-border pollution. In the early 1970s, the United States and Canada launched a debate on transboundary acid rain problem; in the beginning of the establishment of the North American Free Trade Area, clearly define the related content and environmental protection; North American Agreement on Environmental Cooperation (NAAEC) is Jimei, Canada and Mexico domestic policy environment, trade and environmental coordination, extensive public in one of the trilateral agreement on environmental cooperation. It can be said that North America has accumulated a wealth of experience in the governance of transboundary pollution, promote environmental cooperation.

1970's, the United States had a dispute with Canada on the issue of acid rain in the northeast region of the problem of acid rain. The region, including the eastern Canadian and the United States, is a relatively dense and industrial area, especially the five Great Lakes coastal region is an important industrial area. SO2 based industrial pollution emissions caused a serious transboundary acid rain. But more difficult problem is that transboundary acid rain is not one-way but two-way: falls within the territory of the acid rain 15\% from Canada's pollution emissions; and falling in the Canadian territory of acid rain is more than half of the source pollution emissions in the United States. Therefore, Canada believes the main responsibility for the dispute of acid rain in the United States, not only because the US has produced more acid rain precursor pollutants, but because the Canadian economy more dependent on forest resources, even if the same intensity of acid rain, Canada would have suffered more serious losses because of the ecological system of soil acidification.

In 1978, the United States and Canada will solve transboundary acid rain formed the on Long-range Transboundary Air Pollution Study protocol group "(LRTAP) and the following year (1979) issued the" on the air quality in the cross-border joint statement "JSTAQ. In order to solve the problem of acid precipitation, the United States and Canada in 1980 further signed a letter of intent. But with the Reagan administration came to power, the United States to the national SO2 and NOX to reduce the performance and the harm of acid rain and the objective evidence of insufficient grounds, a negative attitude towards the cooperation of acid rain acid rain. Therefore, although the two countries on the issue of acid rain in 1985 had a special representative to discuss the issue, but did not achieve the expected progress. Until March 1991, the Bush administration and the Canadian government on the substantial reduction of SO2 and other induced acid rain material this issue reached the air quality agreement (AQF).

From the point of view of pollution from the point of view, the requirements of Canada is understandable, but 
actually it is quite difficult to operate. From a long-term point of view, if North America acidic pollutants can according to the requirements of the clean air act, "continued to decrease; at the same time, energy structure improvement and energy utilization efficiency will naturally be resolved the dispute of acid rain in North America. It is worth mentioning, if lack of importance evaluation of acid rain in the United States and Canada, then focus on the cause of the debate may reduce the.

\section{ASEAN"10 + 3" mechanism for environmental cooperation}

In addition to cross-border cooperation in harnessing the pollution, among other ASEAN countries also focus on transboundary pollution carried out extensive bilateral and multilateral environmental cooperation with neighboring countries, including China, the establishment of the "ASEAN + 3" mechanism for environmental cooperation, as well as "Greater Mekong Basin development" more than this regional environmental cooperation mechanism to strengthen international exchanges and consolidate the bilateral relations.

As environmental protection high-level dialogue mechanism under the ASEAN "10 + 3" cooperation framework of ASEAN Plus Three Environment Ministers Meeting was launched in 1999. Meeting once a year since 2002 to 2011 has been successfully held more than ten meetings. As a meeting of regional environmental cooperation, China, Japan, South Korea and the ASEAN countries together to strengthen the environmental field dialogue, improve the cooperation mechanism and promoting regional environmental cooperation and strengthening bilateral and multilateral and sub-regional environmental cooperation, we launched a series of work. As a regional cooperation organization by a majority of developing countries, despite a late start, but ASEAN cooperation in the environmental field is still a series of useful attempt, and achieved fruitful results: "regional smog Action Plan" and "Prevention of Cross-Border sign smog agreement "to establish a forest fire prevention and control of transboundary smog coordination mechanism; the coastal waters of the South China Sea project with ASEAN mechanisms to strengthen the integrated management of coral reefs, sea grasses and mangroves protection; marine water quality standards in the ASEAN region, ASEAN National Marine Sanctuary standards, ASEAN maritime heritage of regional standards established to help marine solid liquid and hazardous waste management, coastal marshes and coastal degradation of marine and coastal management and other environmental protection; in the protection of biodiversity, ASEAN established a number of national natural resources conservation areas, national parks and protected areas of genetic species; organized and "ASEAN Environmental Education Action Plan" and other policies enacted, and various kinds of "environment" activities to further strengthen environmental cooperation among ASEAN countries to enhance the people's awareness of environmental protection.

\section{CONSIDERATIONS BASED ON INTERNATIONAL EXPERIENCE}

\section{A. Experience}

Any system that can be put into practice indispensable must include the following three elements "the social acceptance of informal constraints", "the state official constraints" and "implementation mechanism", or institutional environment, institutional arrangements and enforcement mechanisms.

According to Finland's cooperation with the former Soviet Union, in the acid rain prevention in Kazakhstan and China, we can do the following aspects, in order to contribute to coordinated management, China and Kazakhstan as the signed party of transboundary river basin management agreements, two countries set up a special committee to acid rain control will carry out on behalf of their respective management in river basin management committee to coordinate its good offices, while promoting the implementation of environmental legislation in Kazakhstan and China, and the contradiction in watershed management for final arbitration, It is also responsible for the preparation of relevant technical guidance document.

According to the North American experience, China and Kazakhstan both sides can add environmental terms of the agreement in a trade or other agreements in (1) international environmental treaties (such as the Montreal Convention) in preference to the legal effect of the relevant provisions of the Free Trade Agreement; (2) the protection of national safeguard the rights of its environmental levels; (3) the environment must satisfy the principle of determining the level of "adequate scientific", that is, different level of environmental protection must be established on the basis of risk appraisal condition, scientific studies on the economic conditions; (4) Any country shall not be at the expense of environmental quality to attract investment; (5) environment-related trade disputes can only choose either NAFTA or WTO Settlement Mechanism and shall not be changed; (6) The panel may convene the relevant principle of voluntary environmental scientist or expert; (7) Dispute Settlement costs borne by using the principle of prosecution.

\section{B. Difference Analysis and promotion experience}

Unlike the EU, China and Kazakhstan there is not a cross-border region can co-ordination "supranational" institutional relations between countries in the region; at the same time, unlike in North America that have a great appeal core countries. Therefore, to achieve normalization and institutionalization of Kazakhstan transboundary pollution of transboundary cooperation, it must first form a benefit associated mechanism between China and Kazakhstan in transboundary countries. This mechanism may prompt countries to ensure the interests of all countries at the same time improve the domestic environment, thus helping to resolve regional transboundary pollution problems, improve the overall environmental quality of the area.

As can be seen from the previous experience of bilateral trade between the two countries can jointly benefit one or more countries join together, through trade - related agreements signed environment is an effective level to 
enhance regional environmental cooperation "selective incentives" mechanism. To achieve this goal, the primary task at this stage is to improve the situation that regional trade level between China and Kazakhstan, and demands among national interest dispersed greatly: first, to deepen regional division network, expanding the regional final consumer market. Kazakhstan region from cross-border trade commodity structure, the primary product in the region in recent years, particularly sustained increase in imports of energy resources. Economies of scale associated with the agreement to reduce tariffs by the way make the local environment industry to further improve the environmental situation in the area; but also led to the local environment of industrial technology transfer, technology gap between developed and developing cleaner production. With increasing frequency of trade, countries will increasingly close links the region to help promote mutual understanding, enhance mutual trust level. Strengthen trade and economic cooperation, inter-State relations tightness improvement, not only for trade - to create the basis of the establishment of environment-related agreements, but also for institutionalized, normalized Kazakhstan transboundary regional environmental cooperation has provided an opportunity.

\section{CONCLUSION}

There are in common in some degree with classic international cooperation in cross-contamination in China and Kazakhstan, but there are also different. Through empirical analysis, coordination of trade and environment plays a very important role in the process of pollution of transboundary effects. In trade, the only country suffering from domestic pollution will have a natural comparative advantage. Therefore, States have a natural incentive in making pollutant emissions over the world.

China and Kazakhstan on the cross-border region, since the property is difficult to define environmental resources, and lack of a "super-state" machine structure. Therefore, the key to solve pollution problems of ChinaKazakh transboundary, is to seek a way to meet the feasibility, fairness and "tool set" effectiveness.

\section{REFERENCE}

[1] Environment Ministers Meeting in Japan and South Korea official website, www.temm.org.

[2] Acid Deposition Monitoring Network in East Asia. Report of the First Session of the Intergovermental Meeting. Yokohama:EANET,1998; EASNET,http://www.eanet.cn/index.html.

[3] Ding Jinguang. International environmental diplomacy [M]. Beijing: China Social Sciences Press, 2007:201-203.

[4] Asian Development Bank. Regional Master Plan for the Prevention and Control of Dust and Sanstorms in Northeast Asia, Volume 1-3: A Master Plan for Regional Cooperation for the Prevention and Control of Dust and Sandstorms. ADB, 2005.

[5] R.H.Coase. The Problem of Social Cost [J]. Journal of Law and Economics, Vol.3. (Oct.1960).pp.1-44.

[6] http://www.chinalawedu.com/falvfagui/fg23155/181012.shtml.

[7] Government of People's Republic of China and the Russian Federation Agreement on Environmental Cooperation [A]. http://www.hflib.gov.cn/law/law/falvfagui/gjty/hj/hj1012.htm.

[8] Asian Development Bank. Regional Master Plan for the Prevention and Control of Dust and Sanstorms in Northeast Asia, Volume 1-3: A Master Plan for Regional Cooperation for the Prevention and Control of Dust and Sandstorms. ADB, 2005.

[9] R.H.Coase. The Problem of Social Cost [J]. Journal of Law and Economics, Vol.3. (Oct.1960).pp.1-44.

[10] Shafik.N. Economic Development and Environmental Quality: An Econometric Analysis [J]. Oxford Economic Papers, 1994, 46:757-773.

[11] Selden.T, Song.D. Environmental Quality and Development: is there a Kuznets Curve for Air Pollution Emissions [J]. Jounal of environmental economics and management, 1994, 27:147-162.

[12] Xapapadeas.A, Amri.E. Environmental Quality and Economic Development: Empirical Evidence Based on Qualitative Characteristics [J]. Nota di Lavoro Fondazione Eni Enrico Mattei, 1995.

[13] Grossman, G. and A. Krueger. Economic Growth and the Environment [J]. Quarterly Journal of Economics, 110, no. 441, May, 1995.

[14] Cole, M A.Trade, the Pollution Haven Hypothesis and the Environmental Kuznets Curve: Examining the Linkages [J]. Ecological Economics, 2004, 48:71-81.

[15] Stern.D.I, A. Auld, M.S. Common and K.K.Sayal. Is there an environmental Kuznets curve for sulfur? Working Papers in Ecological Economics. 9804, Center for Resource and Environrnental Studzes, Australian National University, Canberra, 1998. 